\title{
TRIPLE TIME IN ENGLISH VERSE
}

\author{
Martin J. DufFell
}

Resumen: Anteriores artículos (Duffell 2002 y 2008) identificaron debilidades y omisiones en la descripción de la teoría paramétrica de los metros ingleses binarios, mientras que el presente examina los parámetros de los metros ternarios y de los dolniks. Sostiene que: (1) el lugar de prominencia de los metros ternarios deben ser posiciones fuertes y el tipo de prominencia el acento; y (2) los metros del dolnik usan muy poca tensión, dado que tienen otras fuentes incorporadas de variación métrica. Concluye notando, a partir de Tanlinskaja (1993), que los metros ingleses forman un continuo, y confirmando la hipótesis de Hanson \& Kiparsky (1966) de que los metros evolucionan para acoger el léxico de una lengua determinada y reflejan sus cambios fonológicos.

Palabras clave: Teoría paramétrica, métrica rusa, metros binarios, metros ternarios, lugar de prominencia, tipo de prominencia, dolniks, principio de encaje.

\footnotetext{
Abstract: Previous articles (Duffell 2002 and 2008) identified weakness or omissions in parametric theory's description of English binary metres, while the present article examines the parameters of ternary metres and dolniks. It argues that: (1) the prominence site of ternary metres must be strong positions and the prominence type stress; and (2) dolnik metres employ very little tension, since they have other, in-built, sources of metrical variety. It concludes by noting the evidence from Tarlinskaja 1993 that English metres form a continuum, and by confirming the hypothesis of Hanson \& Kiparsky 1996 that metres evolve so as to accommodate the lexicon of the language concerned and reflect phonological changes in it.
} 
Key words: Parametric theory, Russian metrics, binary metres, ternary metres, prominence site, prominence type, dolniks, principle of fit. 


\section{Syllables, Stress Peaks, and Intervals}

M

OST versifying in English has been based upon the counting of either syllables or peaks of stress, or upon the patterning of these two features. ${ }^{1}$ English Verse is thus a stylisation of the language, an artificially regular version of normal speech, where some syllables carry stress peaks and others form the intervals between them. ${ }^{2}$ In normal English speech the most common interval between major peaks is one of three syllables, with a minor peak on the middle of the three (Hogg \& McCully 1987: 2 \& 148-50), so that the predominant rhythm is duple time, and the most common interval between peaks is that of one syllable. In contrast, intervals of two syllables, which produce a triple-time rhythm, account for only 33 per cent of all intervals (Tarlinskaja 1993: 43). ${ }^{3}$ The metres in which most English verse has been composed have a binary (iambic) regularity, an exaggerated stylisation of the language's dominant duple-time rhythm, in which alternate syllables represent peaks. In verse the syllables on which these peaks are expected are termed beats, or ictuses, and the intervals between them, whether

${ }^{1}$ The properties that distinguish stressed from unstressed syllables in English are greater length, greater volume, and a rise in pitch (Fry 1958); although laboratory experiments suggest that stress is a continuum, the aspect of it most relevant to metre is whether a syllable has more stress than its neighbours (see Halle \& Keyser 1966 and Liberman \& Prince 1977).

${ }^{2}$ In order to prevent such an artificial construct becoming monotonous most verse tolerates occasional departures from regularity, usually termed tension (see Dorchain 1919: 22-23, Allen 1973: 110, and Fabb 2001: 786); the present article is thus a study of regularity and tension in English metre.

${ }^{3}$ Marina Tarlinskaja used samples from the prose of nineteenth-century English novelists in her calculation (1993: 33-35); my own research into English prose rhythms, which was based on works from the fourteenth, seventeenth, and twentieth centuries, confirms her results. 
of one syllable or more, are described as inter-ictic. Although triple-time rhythm is the exception in prose, it can be found in a number of English metres (see Weismiller 1989), and this article will be devoted to studying three contexts in which disyllabic intervals occur: metres where they are exceptional, metres where they are common, and metres where they are the norm. It will present a statistical analyse of a series of verse samples of each type, test modern explanations of triple time against the data produced, and draw some conclusions from it on the typology of English metres.

\section{Triple Time in English Binary Metres}

Most of the work published on modern linguistic metrics has focused on the binary metre that became the English long-line canon, the iambic pentameter (see, for example, Halle \& Keyser 1966, Hanson 1995, and Hanson \& Kiparsky 1996). ${ }^{4}$ Several studies have also been devoted to binary, metres with a trochaic rhythm (see, for example, Hascall 1971, Bjorkland 1989, and Duffell 2008). From these studies it is clear that triple time and disyllabic intervals occur by exception in iambic metres and they are even more restricted in trochaic; in English iambic metres disyllabic intervals are the result of one of two types of tension, either inversion, where a trochee replaces and iamb and creates a disyllabic interval with the following iamb, or substitution, where an anapaest replaces and iamb. ${ }^{5}$ Some modern metrists, however, have offered new explanations of tension and of disyllabic intervals in iambic verse, and one of the most concise and original is that proposed by Kristin Hanson and Paul Kiparsky. Their parametric theory (1996) is one of several hypotheses advanced by modern linguistic metrics that employ the concept of a metre as a verse design capable of generating actual lines, or verse instances (see Jakobson 1960: 364-65). Within this

\footnotetext{
${ }^{4}$ For a detailed account of the iambic pentameter's evolution and its history between 1378 and 1580, see Duffell 2000a, 2000b, 2002, 2003, Duffell \& Billy 2004.

${ }^{5}$ Modern linguistic metrics has embraced the Classical terms for feet that contain weak (w) and strong (s) elements in different configurations: the iamb [w s], the trochee [ $\mathrm{s} \mathrm{w}]$, the anapaest [w w s], the dactyl [s w w], and the amphibrach [w s $\mathrm{w}]$.
} 
concept, a verse design is divisible into a template, or abstract pattern, and a set of correspondence rules governing the type of linguistic material in verse instances that may correspond to each position in the template.

Hanson \& Kiparsky argue that all metres may be defined by five key features, or parameters, two of which are properties of the template: position number, the number of contrastive (strong or weak) positions it contains, and orientation (whether its weak (w) positions precede or follow its strong (s) ones). The iambic pentameter, according to parametric theory, thus has a template of ten right-strong (w s) positions. A metre's remaining parameters summarize its correspondence rules: position size is the maximum amount of linguistic material in instances that may correspond to a position of the template, and prominence type is the category of linguistic material that the design constrains from appearing in the prominence site, which may be weak positions or, strong, or both. Hanson \& Kiparsky 1996 argues that in most English poets' iambic pentameters the position-size parameter is one syllable and that the metre's prominence parameters constrain the strong syllables of polysyllabic words (those with greater stress than their neighbours) from appearing in weak positions. ${ }^{6}$ These correspondence rules, however, are subject to specific exceptions, in order to make maximum use of the English lexicon in the metre. Thus English has a number of words like for-ti-fi-ca-tion with a disyllabic interval between the secondary stress (underlined) and the primary (in bold typeface), and the exceptions conveniently accommodate them.

According to parametric theory, disyllabic intervals are allowed in English iambic pentameters on two accounts, the first of which is that prominence constraints are looser at the beginning of lines and stricter at their close (the closure principle). This allows inversion (a trochee replacing an iamb) both at the beginning of the line (initial inversion) and after a major syn-

\footnotetext{
${ }^{6}$ The distinction between stress and strength can be illustrated simply thus: both syllables of the word rep-tile have a measure of stress, but only first is strong, while in the word Bir-ming-ham, the first syllable has primary stress, and is therefore strong, but in US English the third is also stressed sufficiently to make it stronger than its neighbour.
} 
tactic boundary within it (medial inversion). ${ }^{7}$ Although medial inversion is by far the less common, it can be found, for example, in the following line from Tennyson's poem Ulysses: ${ }^{8}$

(1) Much have I seen and known: ci-ties of men

In addition to the medial inversion of 'cities', this line contains a monosyllabic initial inversion, but parametric theory does not recognize such inversions, because it make the metre's prominence type strength, not stress; yet all normal deliveries of this line give phrasal stress to its first syllable. Parametric theory thus accounts only for polysyllabic inversion, which occurs initially in \pm 5 per cent and medially in \pm 1 per cent of most English poets' iambic pentameters lines: it ignores monosyllabic inversions such as occur in the following line, probably the best known iambic pentameter of all:

(2) To be or not to be: that is the ques-tion

Monosyllabic inversions are rather more common than polysyllabic in English (where over 70 per cent of words are monosyllables) but, since the aim of this section is to test what parametric theory predicts, not what it ignores, they will not be included in the calculations that follow. ${ }^{9}$

Parametric theory also allows disyllabic intervals in this metre for a second reason: the poet may choose to make his position size not one syllable, but one foot. Thus Hanson argues

${ }^{7}$ Inversion not attributable to the closure principle is rare, and is limited to situations where a lexical trochee corresponds to a weak-strong contrast in the template. This is termed the bracketing condition by Hanson \& Kiparsky because the lexical foot and the poetic foot have the same boundaries.

${ }^{8}$ I employ the following scansion aids in my examples: extra space is left between words; syllables in the same word are separated by hyphens; strong syllables are in bold typeface; other syllables that represent beats are underlined; inversions are highlighted by italics; zero anacruses and intervals (void weak positions) are indicated by $[\mathrm{V}]$.

${ }^{9}$ As Nigel Fabb points out, parametric theory underdetermines the properties of the English iambic pentameter (2001: 778). I have shown elsewhere that it fails to account for the variation in mid-line word boundaries that passages in the metre exhibit (Duffell 2002), and that it ignores a constraint against two consecutive strong positions' lacking stress (Duffell 2008). 
that, while Milton's pentameter is syllable-based, Shakespeare's is foot-based, making his maximum position size one heavy syllable, two light syllables of which the first is stressed, or a series of unstressed light syllables. ${ }^{10}$

Hanson illustrates her hypothesis using lines from Shakespeare's sonnets (1592) and a relatively late play, King Lear (1604), but her arguments for a foot-based metre in the former should be challenged. At first sight there appear to be disyllabic intervals in lines such as the following from the sonnets (Alexander 1958):

(3) Kno-wing a be-tter spirit doth use your name

(4) And trouble deaf hea-ven with my boot-less cries

(5) Being had to tri-umph, be-ing lack'd to hope

(6) Weeds a-mong weeds, or flowers with flo-wers gathered

The candidates for disyllabic intervals in these lines, however, require closer scrutiny: the first interval of (3) is disyllabic as the result of initial inversion, not substitution, and the third is disyllabic only if 'spirit' counts as two syllables (as it does in 129.1). Similarly the first two intervals of (4) are disyllabic only if 'trouble' and 'heaven' count as two syllables (as the latter word does in 21.12 and 29.3). The words 'being' (5), and 'flowers' (6) are similarly ambivalent in syllable count: they can be pronounced as two syllables or as one (particularly in the Cockney pronunciation of the last word). All these words are covered by what Paul Kiparsky termed prosodic rules (1977: 190), which apply to speech and prose, as well as verse. Hanson, too, lists a number of words that are 'for all poets in the English tradition [...] optionally monosyllabic' (1995: 73), and she notes that Milton sometimes counts sequences of two vowels as one syllable, even when they are in different words (1995: 72). ${ }^{11}$ Since

\footnotetext{
${ }^{10}$ According to moraic theory syllables are light if they occupy the minimum delivery time of one mora, and heavy if they occupy two moras. One heavy or two light syllables are held to constitute a moraic foot, which in English is always leftstrong, or trochaic (see Hayes 1995: 62-84). The hypothesis that English has such a binary moraic structure is strongly supported by the fact that it contains no light (single-mora) lexical monosyllables (see Getty 2002: 8).

${ }^{11}$ When adjacent vowels in different words are so reduced it is termed elision, which in some periods has been recognized in English orthography; thus in instance (10)
} 
Hanson classifies Milton's pentameter as syllable-based, then the metre of Shakespeare's sonnets, which shares its parameters, must also be syllable-based..$^{12}$ Certainly the poets of Shakespeare's time believed that the linguistic units they counted in their versifying were syllables, as Hanson acknowledges (1995: 71). There is certainly no reason to doubt that belief in the case of Shakespeare's sonnets, which followed a metrical vogue set by Sir Philip Sidney (b. 1554, d. 1586), himself a confessed counter of syllables (see Van Dorsten 1966: 73).

\section{The Dramatic Iambic Pentameter}

Although Hanson's evidence for a foot-based pentameter in King Lear is far stronger, it is important note that these lines differ from those in the sonnets by being dialogue for stage performance. And it is clear that the iambic pentameters of Elizabethan and Jacobean drama had a number of distinctive features, all of which made the verse more like normal speech (see Tarlinskaja 1976: 159-83). Perhaps the most obvious of these features was an absence of rhyme (making the metre blank verse), but others are quantifiable, and the frequency with which they occur may easily be calculated. ${ }^{13}$ Table I at the end of this article shows the percentage of lines in five samples of dramatic verse that contain initial or medial inversion, enjambment, feminine endings, and intervals of zero or two syllables. All the verse in these samples was composed within a period of sixty years around the composition of Shakespeare's sonnets (1592), for which I give figures

\footnotetext{
'the advice' is written 'th'advice'. Edward Weismiller lists well over 200 word groups in which adjacent vowels have sometimes been reduced to one syllable and sometimes counted in full (1989: 288-89).

12 More than a generation separates William Shakespeare (b.1564, d. 1616) from John Milton (b. 1608, d. 1674); Hanson would have been on firmer ground had she based her case for a foot-based pentameter on the poetry of Shakespeare's younger contemporary, John Donne (b. 1572, d. 1631), or of a number of nineteenth-century poets, all of whom must have been familiar with the foot-based pentameters of Shakespeare's later plays (see Weismiller 1989: 265-82).

${ }^{13}$ Blank verse was first employed in English by Henry Howard, Earl of Surrey (b. ?1517, d. 1547), in his translation of Virgil's Aeneid (Keene 1985); it became the metre of Elizabethan and Jacobean drama after Thomas Norton (b.1532, d. 1584) and Thomas Sackville (b.1536, d. 1608) chose it for their play Gorboduc (Tydeman 1992), which was staged before the queen in 1562.
} 
to aid comparison. Two of the samples are from Norton and Sackville's Gorboduc (1560), one by each author; two are from Shakespeare's plays, Richard III (1590) and Anthony and Cleopatra (1606), and the final sample is from The Duchess of Malfi (1613) by John Webster (b. ?1578, d.?1632). ${ }^{14}$

The figures in the table show that Shakespeare only rarely admitted lines with disyllabic intervals in his early plays, but employed them much more liberally later. Lines with intervals of other than one syllable are rare in Richard III but not uncommon in either King Lear or Anthony and Cleopatra: instances (5) to (10) combine four from my own samples with two quoted by Hanson 1995:

(7) And that the Queen's kin-dred are made gen-tle-folk

(8) His pow'r-ful man-date to you: 'Do this and this'

$(R I I 1,1.1 .95)$

(9) Call in the mes-sengers. As I am E-gypt's Queen

(10) As you shall give th'ad-vice. [V] By the fire

(11) As flies to wan-ton boys are we to the gods

(12) Pray you now for-get, and for-give; I am old and foo-lish

Instances (7), (8), and (11) have only one disyllabic interval, but (12) has three, while the third interval in (9) contains three unstressed syllables, and that of (10) is void (a zero interval). All these examples offer support for Hanson and Kiparsky's hypothesis that in some English iambic pentameters the maximum size of a position is one foot.

The argument that all Shakespeare's pentameters are footbased, however, is unsustainable: those of the sonnets are clearly not, and evidence from the early plays is very thin. The scarcity of possible examples in Gorboduc and, still more so, in the works (Steane 1969) of Christopher Marlowe (b. 1564, d. 1593) suggest that expanding position size was largely Shakespeare's

\footnotetext{
$\overline{{ }^{14}}$ The samples analysed are the first and last 300 lines of Gorboduc (Tydeman 1992), the former of which are by Norton and the latter by Sackville; the first 300 lines of Shakespeare's Sonnets, Richard III, and Anthony and Cleopatra (Alexander 1958); and the first 300 lines of Act IV, of The Duchess of Malfi (Lucas 1927); only lines spoken by a single character are included in the dramatic samples. The statistical implications of employing samples in this analysis are discussed at the foot of Table I.
} 
innovation. But there can be no doubt that the most enthusiastic exponent of the device was John Webster, as the following examples from The Duchess of Malfi show:

(13) From true le-gi-ti-mate is-sue: com-pas-sio-nate na-ture

(14) And the hand as sure as the ring; and doe not doubt

(15) O, but you must re-mem-ber, my curse hath a great way to go

(16) Ne-ces-si-ty makes me suf-fer con-stan-tly

In total 44 per cent of lines in my Webster sample contain an interval of more or less than one syllable, a proportion similar to that found by F. L. Lucas, who used a different and slightly larger and sample (1927, IV: 291). Moreover many of Webster's lines contain more than one disyllabic interval (thus instance (13) contains three and (15) four), and some lines contain trisyllabic or zero intervals, like the following:

(17) I bad thee when I was dis-trac-ted of my wits

(18) To store them with fresh co-lour: who's [V] there?

In my sample well over 10 per cent of Webster's inter-ictic intervals contain other than a single syllable, but such flexibility in position size is sometimes a source of metrical ambiguity: thus (17) is indistinguishable from an iambic hexameter with 'of' representing an ictus; since lines of other lengths other are occasionally admitted by Webster, it is impossible to be sure that his metrical intention in (17) was not a stray alexandrine.

The other columns in Table I refer to other metrical features that distinguish Shakespeare's late works and Webster's plays from most other iambic pentameters. The figures in this table show that, in addition to numerous disyllabic intervals, these works employ slightly more inversion, much more frequent enjambment, and far more feminine endings (for which, of course, no rhyme is required in blank verse). All these features bring the lines of these dramas closer to the norms of English speech, but Lucas argued that in his last plays Webster retreated from this ambitious attempt to capture the rhythms of prose (1927, IV: 250-56). English theatres were forced to close under the Com- 
monwealth and when they re-opened in the 1660s playwrights reverted to the strict iambic line in rhymed heroic couplets. Webster's metre, however, did not disappear: it has survived in the verse of many twentieth century English poets. ${ }^{15}$

\section{The English Dolnik}

In addition to diachronic change in Webster's use of disyllabic intervals, F. L. Lucas noted the similarity between his metrics and older modes of versifying in English:

There are times $[\ldots]$ when he seems to revert in effect to the older English system of simply counting the accented syllables and ignoring the number of accented ones (1927, IV: 251n1).

In the earliest English verse, such as the epic composed on the Battle of Malden (AD 991; see Scragg 1991), the size of weak positions is largely unconstrained: they may contain several syllables, one or more of which may have a measure of stress. In late-Middle English this type of metre gradually evolved into verse in which weak positions contained between zero and two syllables (see Duffell 2000a), but by the late sixteenth century it was restricted by cultured poets to their imitations of folk verse; only in the late eighteenth century did such verse re-emerge as a serious rival to strictly stress-syllabic metres. ${ }^{16}$ A variety of terms have been used for English verse designs that allow variable intervals: since the generative metrists' preferred term iambic-anapaestic metre is very long, and the terms looser iambic metre, sprung verse, and strict stress-metre are easily confused with more familiar terms for other types of verse, I shall use the

\footnotetext{
${ }^{15}$ The foot-based pentameter has been a favourite long line of many of the century's most famous poets, including T. S. Eliot (b. 1888, d. 1965), W. H. Auden (b. 1907, d. 1973), A. D. Hope (b. 1907, d. 2000), Dylan Thomas (b. 1914, d. 1963), Robert Lowell (b. 1917, d. 1977), Ted Hughes (b. 1930, d. 2000), Seamus Heaney (b. 1939), and Robert Pinsky (b. 1940).

${ }^{16}$ Sixteenth-century examples of such a metre, by then termed tumbling verse, can be found in The Shepheardes Calender (McCabe 1999) by Edmund Spenser (b. 1552 , d. 1599); its eighteenth-century revival was inspired by the publication of The Reliques of Ancient English Poetry (Prichard 1892-93) by Thomas Percy (b. 1729, d. 1811).
} 
concise Russian term dolnik in this article, where I shall examine the rhythms of three extremely well known (and well crafted) examples, the first two briefly and the third in greater detail. The first two examples are by Alfred Tennyson (b. 1807, d. 1980): his twelve-line poem 'Break, break, break' and his much longer work Maud (both in Ricks 1987). The third example is the The Statue and the Bust (Jack 1970) by Robert Browning (b. 1812, d. 1889), a poem of 250 lines.

The following lines from Tennyson's shorter poem demonstrate some of the most important features of dolnik verse in general:

(19) [V] Break, [V] break, [V] break

(20) on thy cold grey stones, O sea

(21) the thoughts that a-rise in me

(22) but, oh, for the touch of a va-nished hand

Both the inter-ictic intervals of (19) contain zero syllables, both those of (20) contain one, but in (21) and (22) intervals of one and two syllables are combined. In the English dolnik zero intervals are rare and mainly used for special effects, as in (20), where they echo the waves and are metaphors for the poet's emotional state. In this poem 56 per cent of intervals are disyllabic, a significantly higher proportion than that found in normal speech ( 33 per cent): this exaggeration, too, may be mimetic, since waves break irregularly, and at what sometimes seem relatively long intervals. Another feature discernible in the above examples is that lines in this type of metre also vary in the number of syllables (again between zero and two) before their first beat. Generative metrists normally describe this initial variability as being a void initial weak position, but most other metrists prefer the term anacrusis. Thus (19) has zero anacrusic syllables, (20) has two, and both (21) and (22) have a single syllable in anacrusis. As a further source of variety, the penultimate line (22) has four beats, so that this poem ends with the traditional common measure of English folk verse. ${ }^{17}$ Disyllabic po-

17 Derek Attridge argues that the three-beat lines of common measure are simply four-beat lines with an unrealised final beat (1982: 84-102). In Attridge's theory of English verse rhythm stress-syllabic verse is characterized as a type of dolnik 
sitions, the anacrusic principle, and the rhythmic compatibility of three- and four-ictic lines thus constitute the essence of the English dolnik.

Tennyson's Maud is a poem of over 1400 lines, divided unevenly into three parts and twenty-eight sections, and it is a showcase of dolnik metres. The first four sections are in six-ictic lines, but those that follow may be in three- or four-ictic, or a mixture of the two; these sections also contain isolated two-ictic lines, and the lines of the final section are five-ictic. ${ }^{18}$ Instances (23) to (25), below, contain two, three, and four ictuses, respectively, while (26) and (27) contain five-ictic and (28) and (29) six-ictic lines:

(23) [V] Long [V] dead!

(24) A voice by the ce-dar tree

(25) [V] Mor-ning a-ri-ses stor-my and pale

(26) It is bet-ter to fight for the good, than to rail at the ill

(27) I em-brace the pur-pose of God, and the doom as-signed

(28) I hate the dread-ful hol-low be-hind the lit-tle wood

(29) I will bu-ry my-self in my-self and the De-vil may pipe to his own

As these lines show, the anacrusic principle is an important feature of Maud's versification, and the poem's inter-ictic intervals may contain one or two syllables. Longer lines may be predominantly in duple time like (28), or in triple like (26) and (29), but most contain a mixture of rhythms like (24), (25), and (27). In total 46.3 per cent of the poem's inter-ictic intervals contain two syllables, a significantly higher proportion than the 33 per cent of English prose.

In all the line lengths he employs in Maud Tennyson takes great care to avoid the regular iambic line (although his opening line (28) comes perilously close). It is tempting to read into this

in which double offbeats (disyllabic intervals) must be balanced by zero offbeats (zero intervals). Although comprehensive and elegant, this theory ignores the fact that the English poets who developed the first stress-syllabic metres thought they were counting syllables. It also makes little use of the concept of the foot, which is so important to the hypotheses of generative metrists.

18 The dolniks of Maud are thus heterogeneous, in contrast to the homogeneous dolniks (all four-ictic) of The Statue and the Bust. 
poem a metaphor for the poet's innovative metrics, with instance (29) proclaiming a rebellion against the canonical English pentameter, and instance (27) accepting defeat at the poem's close. Nevertheless, even in the final section Tennyson eschews the iambic canon, and his poem's lines contain far more triple time than Webster's foot-based pentameters. In summary, Maud is a tour de force of syllabically irregular versifying, and it contains an impressive variety in line length, rhythm, and rhyme scheme. This poem is proof of Tennyson's range and skill as a versifier, but its high proportion of triple time makes its artifice conspicuous and possibly detracts from the delivery of the poet's message. In The Statue and the Bust, on the other hand, Browning chose to tell his story and deliver his moral in lines of a single length, a four-ictic dolnik in the oldest English tradition. The following lines exemplify the poem's rhythmic variety:

(30) she leaned forth, one on ei-ther hand

(31) [V] hol-low-eyed and hag-gard-cheeked

(32) [V] nights and days in the nar-row room

(33) suf-fi-cient to vin-di-cate it-self

(34) the true has no va-lue be-yond the sham

(35) [V] Ven-ture as wa-ri-ly, use the same skills

Table II contains a statistical analysis of the poem's rhythms, and it shows that Browning employed the anacrusic principle freely: just over half of his lines have a single syllable in anacrusis, while 16 per cent have a zero, and 28 per cent a disyllabic anacrusis. Almost exactly one third of the poem's inter-ictic intervals are disyllabic, but they are very unevenly distributed: they represent approximately 43 per cent of first intervals and 49 per cent of second, but only just over 9 per cent of third. Approximately one line in five is in duple time: thus (30) is iambic, while (31) is rendered trochaic by its zero anacrusis. Most lines combine duple and triple time, intervals of one or two syllables: 28 per cent have intervals of 1-2-1 syllables, as in (32), 22 per cent intervals of 2-1-1, as in (33), and 16 per cent intervals of $2-2-1$, as in (34). Only 9 per cent of lines have a disyllabic third interval, like (35), which is the only line on the poem with intervals of 2-2-2 (offset by a zero anacrusis). 
From this analysis it can be seen that Browning's poem is extremely varied in rhythm and thus has much in common with a normal speech narrative. The poem has almost exactly the same proportion of disyllabic intervals found in English prose, and more than 90 per cent of its lines contain a mixture of rhythms (either a disyllabic interval or a disyllabic/zero anacrusis). Its percentage of lines with a disyllabic interval is more than double that of Webster's foot-based pentameter, as is the percentage of intervals that are disyllabic. But the proportion of disyllabic intervals in Tennyson's Maud is even higher, and Tarlinskaja shows that some poems in dolnik have higher proportions still (1993: 213-17). ${ }^{19}$ She also argues that iambic verse forms a continuum both structurally and historically with the dolnik (Tarlinskaja 1976: 84-128) ${ }^{20}$ But, if Webster's line occupies a mid-point between these two metres, the dolnik itself also occupies one between iambic verse and verse in which all the inter-ictic intervals are disyllabic. The latter type of verse is termed ternary or triple-time, and it will form the subject of the next section.

\section{English Ternary Metres}

Ternary metres, those in which all the inter-ictic intervals contain two syllables, have received scant attention from modern metrists, and introductions to English metre for the general reader devote little space to them and usually simplify the issues they raise. Thus G. S. Fraser (1970: 38-40) and John Hollander (1981: 8) note that lines of verse may contain anapaests (w w s) or dactyls ( $\mathrm{s} \mathrm{w} \mathrm{w}$ ), but neither explores the differences between the two rhythms or mentions the possibility of amphibrachs ( $\mathrm{w}$ $\mathrm{s} \mathrm{w}$ ). Writing more recently, Philip Hobsbaum fudges this issue by saying that lines made up of trisyllabic feet usually contain a mixture of patterns (1996: 2), while Robert Pinsky goes one

\footnotetext{
$\overline{19}$ Tarlinskaja argues that the percentage of eroded ictuses in dolniks rises as the percentage of disyllabic intervals falls (1976: 128), and that ictic stress in English ternary metres is not as constant as in Russian (1976: 35). The presence of unstressed English monosyllables in ictic positions, however, is far more common in binary than in ternary metres (see Duffell 2008).

${ }_{20}$ My research strongly supports Tarlinskaja's hypothesis that intermediate forms can usually be found between any two types of metre (1993: 11).
} 
step further, reducing all ternary metres to anapaests (1998: 66). Stephen Fry is even more confusing: he identifies Matthew Prior (b. 1670, d. 1734) as an exponent of the amphibrach, and argues that a limerick may be either amphibrachic or anapaestic, but concludes that amphibrachs have no place in English (2005: 88-90). Scholarly works also play their part in this neglect of ternary verse: generative metrists focus on the binary $(\mathrm{w} / \mathrm{s})$ contrast contained in all metres, and they usually test their hypotheses against the most obviously binary metres and postpone consideration of the structure of ternary feet. Thus Hanson and Kiparsky state explicitly that they have not considered how ternary verse may fit into parameteric theory (1996: 300n21).

In this section I shall examine the question of whether there are three separate types of ternary verse and, if so, what their parameters might be. In that examination I shall employ both generative analysis and statistical methods, and I shall test my hypotheses on three poems by the same poet: Browning's The Lost Leader (hereafter LL), How They Brought the Good News from Ghent to Aix (hereafter $H B$ ), and The Englishman in Italy (hereafter EI). ${ }^{21}$ I have chosen these three poems because they are by a consummate metrist with a long tradition of triple-time verse before him, and because they seem to have very different prevailing rhythms.

All three poems, however, share a number of features that distinguish their verse design from duple-time or binary verse, one of the most obvious of which is that their correspondence rules do not allow inversion. This applies to monosyllabic as well as polysyllabic inversion, since in the very few lines where atonic monosyllables provide ictuses they are never articles, and are usually prepositions, as in the following example: ${ }^{22}$

(36) Shake-speare was of us [V] Mil-ton was for us

(37) And be-twixt the great walls of loose flint-stone or in the thick dust

\footnotetext{
21 Both The Lost Leader and How They Brought the Good News from Ghent to Aix are in tetrameters, while The Englishman in Italy is in pentameters, disguised by the poet's orthography, which subdivides them into units containing three ictuses and two.

22 Many modern writers on linguistics regard prepositions as lexical, not grammatical, words; see, for example, Getty 2002: 3 .
} 
The first of these lines is of particular interest because, at first sight, it appears to contain the only example of substitution (a single-syllable interval, notated by [V] above). But, since this poem's verse design allows anacrusis, the missing syllable probably results from subdividing the line into two hemistichs, like those of tumbling verse, and applying the anacrusic principle to both. ${ }^{23}$

The anacrusic principle clearly operates in all three poems, although none of them contains a mixture of zero, single-syllable, and disyllabic anacruses. Their rhythms also differ at the close of the line: almost half of $L L$ 's lines are feminine, whereas most of $H B$ 's and all of $E I$ 's lines are masculine, as is shown by the figures in Table III. The openings and closes of the poems offer some support for the hypothesis that Browning's three poems are in different metres, $L L$ dactylic, $E I$ anapaestic, and $H B$ amphibrachic. Thus the overwhelming majority of The Lost Leader's lines have zero anacrusis, no line has disyllabic anacrusis, and one line ends in two post-tonic syllables (the first of the following examples):

(38) Best fight on well, for we taught him - strike gal-lant-ly

(39) Then let him re-ceive the new know-ledge and wait us

$(L L, 31)$

These lines support the hypothesis that Browning's template is left-strong (that is, dactylic), and that its correspondence rules allow up to one syllable in anacrusis; similarly, lines like the following support the hypothesis that the template of $E I$ is rightstrong (anapaestic), and that the anacrusic principle allows it to open with an iamb, as in the second of the following: ${ }^{24}$

(40) Let me keep you a-mused till he va-nish in black from the skies

(41) Your eye from the life to be lived in the blue so-li-tudes $(E I, 180)$

\footnotetext{
$\overline{{ }^{23}}$ There are many lines in Spenser's Februarie that have a single-syllable interval midline, which divides the line into two-beat hemistichs; for example, 'so se-mest thou like [V] good fry-day to frowne' (30). Tumbling verse, however, clearly allows other weak positions of a single syllable.

${ }^{24}$ Instance (41) is metrically very interesting because its three-beat hemistich is oxytonic, for which the two-beat hemistich that follows compensates by opening with two unstressed syllables. This emphasizes the anapaestic rhythm, which ensures that the primary stress of 'solitude' is subordinated to the preceding tonic monosyllable, while its secondary stress serves to provide the final peak and rhyme.
} 
Inferring the template of $H B$ is more problematic: it too might be described as anapaestic, because all its lines are masculine and almost half have two syllables in anacrusis like instance (42) below. But the majority of the poem's lines open with a single unstressed syllable, and many divide naturally into four units [w S w] followed by an iamb [w s]; for example, instance (42), which mimics the clatter of horses' hooves:

(42) I gal-loped, Dirck gal-loped, we gal-loped all three

(43) And a-gainst him the cat-tle stood black e-very one

Since iambic closes (masculine endings) are common in amphibrachic metres, where they are described by Classical metrics as catalexis, the template of the poem could equally be classed as an amphibrachic tetrameter that allows one syllable in anacrusis. Like Classical metrics, generative metrics admits amphibrachic feet, but the orientation of amphibrachic templates is problematic, since middle-strong templates would be anomalous. Elsewhere I have argued that such templates are rightstrong (w s), and that their correspondence rules set the size of weak positions at one (unstressed) syllable and that of strong positions at one trochee (Duffell 1999: 67-70). This trochee is usually syllabic initially and medially, but may be moraic (that is, a single heavy syllable) in the final foot. Carlos Piera first proposed such a structure for the amphibrach (1980: 122-27), and it is shown below as a tree diagram, and illustrated by two feet from $H B, 2$ : 


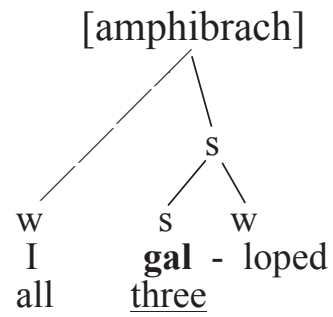

This may be compared with the structure that Paul Kiparsky proposed for the English anapaest (1977: 227-29), and which can be extrapolated to account for the dactyl: Kiparsky terms it a falling structure, and it is illustrated below by feet from $E I, 2$ and $L L, 20$ :
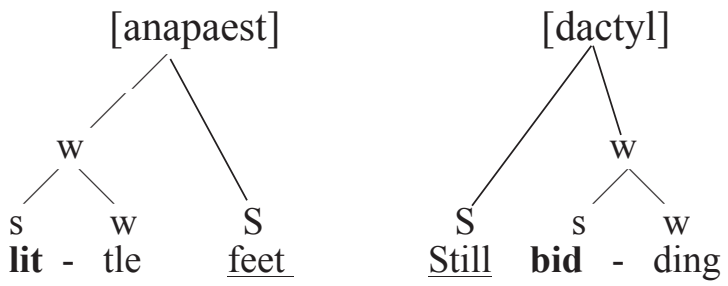

Kiparsky supports such a falling structure by pointing out that the weak positions (or inter-ictic intervals) in one of Byron's triple-time poems contain trochaic, but not iambic words. ${ }^{25}$ This, however, is untrue for my Browning samples; for example, iambic words occur in the inter-ictic intervals of all the following lines:

(44) He a-lone breaks from the van of the free-men

(45) Called Ro-land his pet-name my horse wi-thout peer

(46) At all e-vents come - to the gar-den

From these examples it is clear that iambic words like 'alone'

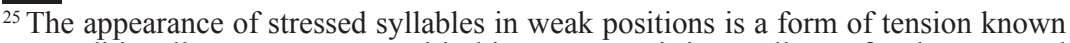
traditionally as incursion, and in binary metres it is usually confined to stressed monosyllables, when it is known as ictus demotion (see Attridge 1982: 168-69), but in ternary metres incursion allows the strong syllables of polysyllabic words to appear in weak positions, or inter-ictic intervals.
} 
(44), 'without' (44), and 'events' may appear in $H B$ 's inter-ictic intervals; moreover, the dactylic $L L$ contains trisyllables with a secondary stress on the final syllable, 'pros-pe-ring' $(L L, 17)$ and 'con-fi-dent' $(L L, 28)$, which exhibit a rising [S w s], rather than falling dactyl [S s w]. Kiparsky's conclusion that there are no rising anapaests in English may well have been the result of sampling error, since Byron's poem is relatively short, but his insight that lexical structures in verse are clues to the poet's metrical intention may still be correct. I have demonstrated elsewhere (Duffell 2008) that a poet seeking a strong trochaic effect uses a greatly enhanced proportion of trochaic words, and the same type of audit of Browning's lexicon in these three poems is illuminating. The proportion of lexical trochees to lexical iambs in English prose is $\pm 4: 1$, and in iambic pentameters is $\pm 3: 1$; comparable figures for Browning's triple-time poems are: $\pm 3: 1$ $(L L), 5: 1(E I)$, and 8:1. $(H B)$. This suggests that in the last of these poems the poet consciously or unconsciously favoured trochaic words, which would support the above hypothesis that his template was amphibrachic and his strong-position size one trochee.

\section{Conclusions}

The foregoing analysis shows that English triple- and duple-time metres differ in three of Hanson \& Kiparsky's parameters: position size, prominence site, and prominence type. In duple-time metres the position size is most often one syllable, the prominence site weak positions, and the prominence type strength. The metrical feet of dactylic and anapaestic metres, on the other hand, contrast a position containing one syllable with a position containing two. Since the latter may contain a disyllabic word with both a strong and a weak syllable, the weak positions of such metres must be unconstrained, and their prominence site can only be strong positions. The prominence type of ternary metres, as of binary, might be argued to be strength, since the weak syllables of polysyllabic words do not appear in strong positions. But in ternary metres atonic monosyllables such as articles may not occupy strong positions, showing that a degree of 
stress (or potential for it) is required in them. This requirement is the corollary of the position-size rule, because an adjacent weak position may contain the primary stress of a disyllabic word, and would preclude an atonic monosyllable's becoming prominent in normal delivery. ${ }^{26}$

The ways that poets introduce rhythmic variety into the two types of metre also differ: inversion and erosion provide it in duple-time verse, and incursion and anacrusic variation in triple time. Hanson \& Kiparsky propose that the evolution of metres is governed by what they term the principle of fit: they evolve in such a way as to make as much of the lexicon available to poets as possible (1996: 294). In English duple-time metres the prominence parameters (weak positions and syllable strength) allow the freest possible use of the language's plentiful stock of monosyllables. ${ }^{27}$ In English triple-time metres different parameters (strong positions and stress) allow the freest possible use of the other word length that abounds in English, the disyllable. Although this article has revealed structural differences between duple and triple time, it has also confirmed that metric typology is a continuum: if the rules of a binary metre are relaxed a little it become foot-based; if they are relaxed a little more it becomes a dolnik; and if triple time is made compulsory instead of optional it becomes a ternary metre, with a new set of rules.

The English metrical system is the result of this evolutionary potential: thus accentual metres became dolniks, foreign syllabic models led to stress-syllabic verse, and free verse evolved from some poets' desire to regulate their language by making lines differ from, rather than resemble, their predecessors. If individual poets' quests for innovation ensured mutation in the evolution of this system, then linguistic change provided the mechanism for selection. In each period the metres that survived were among those that were a good fit for the phonology of the language. And, although metrical fashions were fickle, some features of the earliest English versifying proved constants, such as counting

\footnotetext{
${ }^{26}$ Note that in instances (41) and (43) to (46) all the strong syllables in weak positions are subordinated to adjacent monosyllables that have stress.

${ }^{27}$ The concept of tension is, of course, almost irrelevant to the dolnik, because it contains such a large measure of variety in its very structure.
} 
beats instead of syllables, and varying the quantity of linguistic material at the threshold of the line. Overall, a system evolved that offered many modes of regularity, various devices to ensure variety, and a potential for subtlety that the most skilled versifiers harness to reinforce the meaning of their texts.

\begin{tabular}{|c|c|c|c|c|c|c|}
\hline \multirow[t]{2}{*}{ TABLE I } & \multicolumn{6}{|c|}{ The Dramatic Iambic Pentameter } \\
\hline & inv & sion & inter & & & \\
\hline AMPLE & initial & medial & $\underline{0}$ & $\underline{2}$ & feminine & enjambed \\
\hline $\begin{array}{l}\text { hakespeare } \\
\text { Sonnets }\end{array}$ & 4.7 & 2.0 & 0 & 0 & 13.3 & 6.3 \\
\hline Jorton & 23 & 40 & $<1$ & 13 & 10 & 107 \\
\hline $\begin{array}{l}\text { ackville } \\
\text { Gorboduc }\end{array}$ & 2.7 & 1.0 & 0 & $<1$ & 0 & 15.0 \\
\hline $\begin{array}{l}\text { hakespeare } \\
\text { Richard III }\end{array}$ & 5.0 & 3.3 & $<1$ & 1.7 & 17.0 & 8.3 \\
\hline $\begin{array}{l}\text { hakespeare } \\
\text { Ant. \& } \\
\text { leo. }\end{array}$ & 7.3 & 4.7 & $<1$ & 7.0 & 21.7 & 21.0 \\
\hline $\begin{array}{l}\text { Nebster } \\
\text { Duchess }\end{array}$ & 5.3 & 8.3 & 5.7 & 38.3 & 20.4 & 26.7 \\
\hline $\operatorname{argest} 2 \sigma^{*}$ & \pm 3.1 & \pm 2.3 & \pm 0.3 & \pm 4.0 & \pm 4.8 & \pm 5.1 \\
\hline
\end{tabular}

* Statisticians measure the significance of differences between figures based on samples in standard errors, and a difference exceeding two standard errors $(2 \sigma)$ has a 95 per cent chance of applying not just to the samples, but to the universe (in this case the whole play) from which they are drawn. Differences between the figures in each column of this table are therefore only significant if they exceed the $2 \sigma$ calculation at the foot of the column. Thus, for example, the difference between the percentage of disyllabic intervals in Anthony and Cleopatra and Richard III is significant, while that between the percentages in Richard III and Gorboduc is not. In the text of this article comment is confined to differences that are statistically significant (for an explanation of how standard errors are calculated see any primer of statistics, for example, Clarke and Cooke 1983: 40-52). 
TABLE II The Rhythms of Browning's The Statue and the Bust

\begin{tabular}{|c|c|c|}
\hline anacrusis & $\%$ & $\underline{\text { line ends }}$ \\
\hline zero & 16.4 & masculine \\
\hline disyllabic & 28.8 & feminine \\
\hline$\frac{\text { disyllabic }}{\text { intervals }}$ & $\%$ & $\frac{\text { intervals \& }}{\text { rhythms }}$ \\
\hline 1 & 42.8 & $1-1-1$ \\
\hline 2 & 48.8 & $1-2-1$ \\
\hline 3 & 9.2 & $2-1-1$ \\
\hline all & 33.6 & $2-2-1$ \\
\hline
\end{tabular}

TABLE III Anacrusis and Inversion in Browning's Ternary Verse sample anacrusis incursion line ends $\begin{array}{llllll}0 & 1 & 2 & \text { intervals } & \text { masc. } & \text { fem. prop. }\end{array}$

The Lost Leader $81.3 \quad 18.7$

0

1.4 47

47

6

How They

Brought

$\begin{array}{lll}0 & 55.0 & 45.0\end{array}$

1.7

$100 \quad 0$

0

The

Englishman

$\begin{array}{lll}0 & 40.0 & 60.0\end{array}$

1.292 .0

8.0

0 


\section{Works Cited}

Alexander, P., ed., 1958. William Shakespeare, Complete Works, 4 vols. (London: Collins).

Allen, W. Sidney, 1973. Accent and Rhythm: Prosodic Features of Latin and Greek: A Study in Theory and Reconstruction (Cambridge: Cambridge UP).

Attridge, Derek, 1982. The Rhythms of English Poetry, English Language Series, 14 (London: Longman).

Bjorkland, Beth, 1989. 'Iambic and Trochaic Verse - Major and Minor Keys?', in Kiparsky \& Youmans 1989: 155-81.

Dorchain, Auguste, 1919. L'Art des vers, $2^{\text {nd }}$ ed. (Paris: Garnier). First ed. publ. in 1911.

Duffell, Martin J., 1999. Modern Metrical Theory and the 'Verso de arte mayor', Papers of the Medieval Hispanic Research Seminar, 10 (London: Queen Mary and Westfield College).

_ 2000a. 'Lydgate's Metrical Inventiveness and his Debt to Chaucer', Parergon 18.1 (special issue entitled Medieval English Measures: Studies in Metre and Versification, ed. Ruth Kennedy), pp. 227-49.

_ $2000 \mathrm{~b}$ “"The Craft So Long to Lerne": Chaucer's Invention of the Iambic Pentameter', Chaucer Review, 34 (1999-2000): 26988.

— 2002 . 'The Italian Line in English after Chaucer', Language and Literature, 11: 291-305.

_ 2003. 'The Iambic Pentameter and Its Rivals', Rhythmica, 1: 61-85.

- , 2008. 'Some Observations on English Binary Metres', Language and Literature, 17: 5-20.

—, \& Dominique Billy, 2004. 'From Decasyllable to Pentameter: Gower's Contribution to English Metrics', Chaucer Review, 38 (2003-04): 383-401.

Fabb, Nigel, 2001. 'Weak Monosyllables in Iambic Pentameter Verse and the Communication of Metrical Form', Lingua, 111: 771-90.

Fraser, G. S., 1970. Metre, Rhyme and Free Verse, The Critical Idiom, 8 (London: Methuen).

Fry, Dennis, 1958. 'Experiments in the Perception of Stress', Language and Speech, 1: 126-52.

Fry, Stephen, 2005. The Ode Less Travelled: Unlocking the Poet Within (London: Hutchinson). 
Getty, Michael, 2002. The Meter of 'Beowulf': A Constraint-Based Approach, Topics in English Linguistics, 36 (Berlin and New York: Mouton de Gruyter).

Halle, Morris, \& Samuel J. Keyser, 1966. 'Chaucer and the Study of Prosody', College English, 28 (1966-67): 187-219.

Hanson, Kristin, 1995. 'Prosodic Constituents of Poetic Meter', Proceedings of the West Coast Conference on Formal Linguistics, 13: 62-77.

—,$\&$ Paul Kiparsky, 1996. 'A Parametric Theory of Poetic Meter', Language, 72: 287-335.

Hascall, Dudley L., 1971. 'Trochaic Metre', College English, 33 (197071): 217-26.

Hayes, Bruce, 1995. Metrical Stress Theory: Principles and Case Studies (Chicago: Chicago UP).

Hobsbaum, Philip, 1996. Metre, Rhythm and Verse Form (London and New York: Routledge).

Hogg, Richard M., \& Christopher B. McCully, 1987. Metrical Phonology: a Course Book (Cambridge: Cambridge UP).

Hollander, John, 1981. Rhyme's Reason: A Guide to English Verse (New Haven: Yale UP).

Jack, Ian, ed., 1970. Robert Browning, Poems 1833-1864 (London: Oxford UP).

Jakobson, Roman, 1960. 'Closing Statement: Linguistics and Poetics', in Style and Language, ed. Thomas A. Sebeok (Boston: MIT Press).

Keene, Dennis, ed., 1985. Henry Howard, Earl of Surrey, Selected Poems (Manchester: Carcanet).

Kiparsky, Paul, 1977. 'The Rhythmic Structure of English Verse', Linguistic Inquiry, 8: 189-247.

_, \& Gilbert Youmans, ed., 1989. Phonetics and Phonology, I, Rhythm and Meter (San Diego: Academic Press).

Liberman, Mark Y., \& Alan Prince, 1977. 'On Stress and Linguistic Rhythm', Linguistic Inquiry, 8: 249-336.

Lucas, F. L., ed., 1927. The Complete Works of John Webster, 4 vols (London: Chatto \& Windus).

McCabe, Richard A., ed., 1999. Edmund Spenser, The Minor Poems (Harmondsworth: Penguin Books).

Piera, Carlos José, 1980. 'Spanish Verse and the Theory of Meter', doctoral thesis, Univ. of California, Los Angeles. DAI, 42 (198182): $197 \mathrm{a}$. 
Pinsky, Robert, 1998. The Sounds of Poetry: A Brief Guide (New York: Farrar, Straus \& Giroux).

Prichard, J. V., ed., 1892-93. Thomas Percy, Lord Bishop of Dromore, Reliques of Ancient English Poetry, Consisting of Old Heroic Ballads, Songs and Other Pieces of Our Earlier Poets, Together with Some Few of Later Date, 2 vols (London: Geo. Bell \& Sons).

Ricks, Christopher, ed., 1987. The Poems of Tennyson, $2^{\text {nd }}$ ed., 3 vols (Harlow: Longman).

Scragg, Donald, ed., 1991. The Battle of Maldon, AD 991 (Oxford: Basil Blackwell and The Manchester Centre for Anglo-Saxon Studies).

Steane, J. B., ed., 1969. Christopher Marlowe, The Complete Plays (Harmondsworth: Penguin Books).

Tarlinskaja, Marina,1976. English Verse: Theory and History, De Proprietatibus Litterarum, Series Practica, 17 (The Hague: Mouton).

- 1993. Strict Stress-Meter in English Poetry Compared with German and Russian (Calgary: Calgary UP).

Tydeman, William, ed., 1992. Two Tudor Tragedies: 'Gorboduc' and 'The Spanish Tragedy' (Harmondsworth: Penguin).

Van Dorsten, Jan, ed., 1966. Sidney, A Defence of Poetry (Oxford: Oxford UP).

Weismiller, Edward R., 1989. 'Triple Threats to Duple Rhythm', in Kiparsky \& Youmans 1989: 261-90. 